\title{
The Potential of Brucella Suis Local Isolates as Vaccine Candidate for Controlling Swine Brucellosis In Indonesia
}

\author{
Emy Koestanti Sabdoningrum ${ }^{1}$, Sri Chusniati ${ }^{2}$ Lilik Maslachah $^{3}$,Widya Paramita Lokipitasari ${ }^{1}$ \\ ${ }^{1}$ Departmen of Animal Husbandry, ${ }^{2}$ Department of Microbiology Veterinary, ${ }^{3}$ Department \\ ofBasic Medicine Veterinary, Faculty of Veterinary Medicine, Airlangga University, \\ Campus C Mulyorejo Street Surabaya. Corresponding Author : emykoestanti@yahoo.co.id
}

\begin{abstract}
Brucellosis in pigs is not only causing great economic losses due to a decrease in productivity of livestock but also is zoonotic. Prevention efforts mainly addressed to vaccination and sanitary measures and governance. S19 and RB51 vaccine does not provide protection against infection and abortion in pigs infected with Brucella suis. The purpose of the study was to develop Brucella suis local isolates vaccine as a vaccine candidate against Brucellosis in pigs and then to prevent the spread of brucellosis. The method used laboratory exploration followed by experimental studies using mice. This study used a factorial design. F test analysis used to test the titer of antibodies through CFT methods. The results showed that local isolates attenuated Brucella suis at a concentration of $10^{8}$ were able to show a good antibody titer 128 . This study concluded that Brucella suis local isolates has the ability to protect mice from infection Brucella suis bacteria and has high immunogenicity.
\end{abstract}

Keywords: Brucella suis, Vaccine Candidate, Local isolates

\section{INTRODUCTION}

Brucellosis in pigs is a disease caused by Brucella suis. Brucella can be transferred from one individual to another individual through several ways such as direct contact with body fluids or through the intermediary of the genitals. In pigs, the clinical symptoms of the disease are more common in adult cattle, including abortion, infertility, orchitis and posterior paralysis. Brucellosis in pigs is not only cause great economic losses due to a decrease in productivity of livestock but also zoonotic. Brucellosis is a zoonotic disease that causes intermittent fever in humans. Those affected are generally associated with work such as livestock farmers, veterinarians and abattoir workers. Brucella suis is a zoonotic disease which can be transmitted to humans who eat pork with improper handling and well cooked, although transmission is more often occurs through direct contact with infected animal (Priadi, 1992).

Economic losses due to brucellosis such as decreased demand in market, decreased production, fetus mortality, effect to management system implementation, increased infertility, culling animal, epidemic disease in humans, added expenditures for research and development of technical laboratory, added expenditures for controlling and handling the disease (Sudibyo, 1998). Elimination of the disease either on a group or population is considered as the most effective way to prevent the spread of the disease in pigs (Alton, 1990). Although the disease is 
found to be endemic with a high prevalence in Latin America, Southeast Asia, China and the countries of Oceania (Corbel, 1997). Elimination method performed by test and slaughter with compensation is a way of controlling the swine brucellosis. The implementation of the test and slaughter has not yet optimal due to the lack of compensation costs (Ewalt, et.al, 1997). Prevention efforts mainly addressed to vaccination and sanitary measures and governance. S19 vaccine does not provide protection against infection and abortion in pigs infected with Brucella suis. B. suis Strain 2 (S2) vaccines which was developed in China and was a strain attenuation of Brucella suis type 1 used extensively was experiencing failures (Nicoletti, P. 1990). In solving above problems, it needs to be pursued formation of local strains in order to improve the performance of the vaccine, as a model bacterial vaccine, which is expected to produce a better immune response. Based on the above background it is necessary to do research in the use of Brucella suis local isolates as vaccine candidates brucellosis in pigs, which is expected to produce a potential vaccine for the prevention of Brucellosis disease in Indonesia.

\section{Purpose of the study}

Develop Brucella suis vaccine local isolates as vaccine candidates against brucellosis in pigs, which is expected to prevent the spread of brucellosis. It was also to determine the serological response to study antibody reactions and the progress of Brucella suis vaccine local isolates and S19 also RB51. From the results of this study are expected to obtain information on the condition of brucellosis in pigs and brucellosis vaccine progress in pigs by using brucella suis local isolates.

\section{METHODS}

This study used laboratory exploration and continued with experimental research by design the randomized post test only control group design. In the experiment, animals were grouped into five (5) groups: the first group with no treatment, the second group with positive control infected with Brucella suis local isolates, the third group vaccinated by Brucella abortus S19 vaccine, the fourth group vaccinated by RB51 vaccine and the fifth group vaccinated by Brucella suis local isolates. This research was conducted at the Microbiology Laboratory, Faculty of Veterinary Medicine Airlangga University, and the Center for Veterinary Wates Yogyakarta.

$\mathbf{T}$

\section{he Procedures:}

Five groups of mice, each containing 5 mices were inoculated intramuscularly with a dose of $1 \mathrm{x}$ $10^{6} \mathrm{CFU}$ of Brucella suis local isolates that inactivated intramuscularly injected $0.2 \mathrm{ml}$ per mice, Brucella abortus strain 19 with a dose of $1 \times 10^{6} \mathrm{CFU}$ that injected intramuscularly $0.2 \mathrm{ml}$ per mice, RB51 vaccine with a dose of $0.1 \mathrm{ml}$ that injected intramuscularly per mice. The fourth group, with the same number of mice, acted as negative control and only injected with $0.2 \mathrm{ml}$ of PBS while the fifth group acted as positive control and injected with $0.2 \mathrm{ml}$ of PBS. On the $38^{\text {th }}$ day, all groups were challenged through injection $0.1 \mathrm{ml}$ of $1 \times 10^{6} \mathrm{CFU}$ of Brucella suis local isolates except negative control group. The whole mice were killed on the $15^{\text {th }}$ day postchallenge, the antibody titers were seen with the CFT.

In this research was taken first vaccination and executed one booster. Mice were adapted for 10 days with individual cages completed with husk and feeding a day with water drinking given $a d$ libitum. Vaccination with the division of the group: 
$\mathrm{P} 0(-)=$ without treatment

$\mathrm{PO}(+)=$ without vaccine, infected with Brucella suis local isolates 0.1 intramuscular

P1 = RB51 $0.1 \mathrm{ml}$ intramuscular vaccinated per mice and infected with Brucella suis local isolates $0.1 \mathrm{ml}$ intramuscular per mice

$\mathrm{P} 2=$ Brucella abortus $\mathrm{S} 19$ vaccinated with concentration $1,0 \times 10^{8}$ of $0.2 \mathrm{ml}$ intramuscular per mice and infected with Brucella suis local isolates $0.1 \mathrm{ml}$ intramuscular per mice

$\mathrm{P} 3$ = Brucella suis local isolates vaccinated with concentration $1,0 \times 10^{6}$ of $0.2 \mathrm{ml}$ intramuscular per mice and infected with Brucella suis local isolates $0.1 \mathrm{ml}$ intramuscular per mice

\section{Statistic Analysis}

This study used a completely randomized design. Analysis of variance (ANOVA) used for antibody titer from CFT test results, and used for testing the challenge test. Significant difference value was determined at the $95 \%$ confidence interval.

\section{RESULTS AND DISCUSSION}

This study used indicator of antibody titers which used to assess the ability of vaccine to protect. The antibody titers results can be seen in Table 1 .

Table 1. Antibody titers in Brucella suis for each treatment

\begin{tabular}{|c|c|}
\hline Treatment & Average and Deviation Standard of Antibody Titers \\
\hline P0- & $0^{\mathrm{a}} \pm 0.000$ \\
\hline P0+ & $13^{\mathrm{a}} \pm 12,806$ \\
\hline P S19 & $15^{\mathrm{a}} \pm 12,383$ \\
\hline P RB51 & $27^{\mathrm{a}} \pm 27,592$ \\
\hline P Brucella suis local & $72^{\mathrm{b}} \pm 40,266$ \\
\hline
\end{tabular}

Description: Different superscript showed significant differences among treatments $(\mathrm{p}<0.05)$

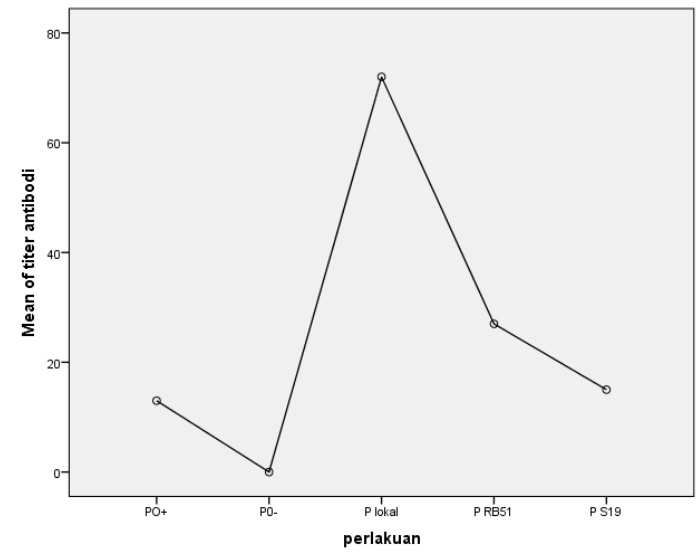

Graphics Antibody Titer

In this study, the indicator used to assess the ability of the vaccine protection was antibody titers. Groups of mice were only inoculated with PBS solution (negative control) resulted to have the lowest antibody titer: 0 (zero) than the other groups. The highest antibody titers on the treatment of inoculated Brucella suis local isolates with titer 128 and followed by RB51 vaccine with titer 64 and strain 19 with titer 32, as well as the positive control with titer 32. Statistics analysis 
showed that antibody titers by treatment with Brucella suis local isolates were different significantly $(\mathrm{P}<0.05)$ compared with the group that received both RB51 vaccine and the group without vaccinated of strain 19. This indicates that inoculation with Brucella suis local isolates strain was successfully stimulates the formation mechanism of high immunity then be able to withstand the infection of B. suis (Bundle, et.al, 1989). The treatment groups that were not significantly different ( $\mathrm{P}>0.05$ ) imply equality potential of both vaccines against Brucella infection. The ability of Brucella suis local isolates to induce weak antibody titers gives advantageous in consideration as a vaccine candidate.

\section{CONCLUSIONS}

This study concluded that Brucella suis local isolates has the ability to protect mice from bacteria infection of Brucella suis, and has high immunogenicity by antibody titers 128 compared with the standard vaccine strain 19 with antibody titers 32 and RB51 with antibody titers 64 .

\section{ACKNOWLEDGEMENTS}

We thank Ditjen DIKTI (Directorate General of Higher Education) for donating this study through scheme Program Penelitian Unggulan Perguruan Tinggi (PUPT) / Universities Leading Research Programme, Decentralization Year 2016.

\section{REFERENCES}

Alton, G.G. 1990. Brucella suis. In: Animal Brucellosis. Edited by: Nielsen, K. and Duncan J.R. CRC Press, Boca Raton, Ann Arbor, Boston. pp: 411-422.

Bundle, D.R., M.B. Perry and Cherwonogrodzky. 1989. Monoclonal antibodies in the identification and characterization of Brucella species. In SWAMINATHAN and Prakash: Nucleic acid monoclonal antibody probes. Marcel Dekker Inc. New York and Basel

Corbel, M.J. 1997. Brucellosis an overview. Emerg. Infect. Dis. 3(2):221

Nicoletti, P. 1990. Vaccination. In: Animal Brucellosis. Edited by: CRC Press, Boca Raton, Ann Arbor, Boston.

Priadi, A. 1992. Brucella suis infection as a zoonosis in Java. Penyakit Hewan 24(44):110-112.

Sudibyo, A 1998. Studi patogenisitas Brucella suis isolat lapang dan kemampuan penularannya dari babi ke manusia. JITV. 3(4):257-263. 